МБО ДО «Харбалахская детская школа искусств»

МР «Таттинский улус» РС (Я)

\title{
КЛАССИЧЕСКИЕ МОДЕЛИ ОРИГАМИ
}

Автор : Антоева Валентина Гаврильевна преподаватель художественного отделения

2020 г. 


\section{СОДЕРЖАНИЕ}

ВВЕДЕНИЕ

I. Общее понятие искусства оригами

1.1. Всеобщее достояние модели из всех базовых форм. Базовые формы

1.2. Модели не квадратной формы

1.3. Взаимосвязь базовых форм

1.4. Условные знаки, принятые в оригами

1.5. Изготовление собственных моделей

ЗАКЛЮЧЕНИЕ

ИСПОЛЬЗОВАННАЯ ЛИТЕРАТУРА

ПРИЛОЖЕНИЯ 
Тема творческого исследования: Оригами. Волшебная страна бумажных моделей

Актуальность: оригами помогает развивать художественный вкус и логику, эффективно способствует формированию пространственного воображения, развивает память, способствует концентрации внимания и самодисциплине, активизирует мыслительные процессы.

Новизна: создание собственных моделей на основе комбинаций базовых форм

Объект исследования: искусство оригами

Предмет исследования: классические модели из базовых форм: треугольник, прямоугольник, книжка, дверь, воздушный змей, блин, рыба, дом, катамаран, водяная бомбочка, лягушка, квадрат, птица

Цель: развить творческие и логические способности, пространственное мышление, активизировать воображение; создать собственную модель

Задачи: изучить систему перехода от одной базовой формы к другой; сориентироваться в разнообразии моделей оригами и усвоить приемы их конструирования; изучить условные знаки, принятые в оригами.

Методы исследования: конструирование на занятиях вариативной части «Стерх-птица счастья»; проведение мастер-класса на региональном фестивале «Кыталык-саха сирин ытык кетере», школьном мероприятии «День журавля», респ.проекте «Семь чудес экологической тропы», республиканском конкурсе «Природа и мы», международном конурсе «Три белых журавля, два пролетных пути, один мир», «Северный форум по устойчивому развитию».

\section{Описание работы}

Оригами - удивительное, загадочное слово. В переводе с японского «ори» означает «сложенньй», а «ками» - «бумага», «бог».

\section{1. Всеобщее достояние модели из всех базовых форм. Изготовление моделей из базовых форм}

Практические работы:

1. Изготовление моделей из базовой формы «Треугольник»: котик, колпак Петрушки, муха, парусник, щенок, каркающая ворона, пятиконечная звезда, золотая рыбка.

2. Изготовление моделей из базовой формы «Книжка»: петушиный гребень, коробка из квадрата, медицинская шапочка, плоскодонка.

3. Изготовление моделей из базовой формы «Дверь»: грибок, кубик, автомобиль, поросенок.

4. Изготовление моделей из базовой формы «Воздушный змей»: восьмиконечная звезда, парусник, воробей, утка, лебедь, японский глайдер. 
5. Изготовление моделей из базовой формы «Блин»: стриж, коробка,водяная лилия, двухтрубный корабль, лошадка.

6. Изготовление моделей из базовой формы «Рыба»: морской котик, кит, шкатулка, карп.

7. Изготовление моделей из базовой формы «Дом»: ферма, пианино, пилотка и портмоне, говорящая лиса.

8. Изготовление моделей из базовой формы «Катамаран»: парусная лодка, бабочка, пахарита, кусудама.

9. Изготовление моделей из базовой формы «Водяная бомбочка»: летучая мышь, лягушка, церковь, надувной заяц, ракета.

10. Изготовление моделей из базовой формы «Квадрат»:тюльпан, цветок, корзинка, елочка в снегу.

11. Изготовление моделей из базовой формы «Птица»: журавль счастья, журавль, машущий крыльями, журавлик на гнезде, мышь, цапля, павлин.

12. Изготовление моделей из базовой формы «Лягушка»: ирис, надувная лягушка, колокольчик.

13. Изготовление моделей из базовой формы «Прямоугольник, треугольник»: сердце, планер, голубь, самолет, письмо, шляпа, аэроглиссер, лодка, птица.

\section{2. Модели не квадратной формы}

Практическая работа:

Изготовление моделей минуя базовые формы: джонка, грач, кукла, каноэ, волчок, звезда.

\section{3. Взаимосвязь базовых форм}

В основе любой поделки лежит определенная заготовка - базовая форма, стройная и понятная система перехода от одной базовой формы к другой. Все базовые формы складываются из квадрата. Умение их складывать позволит быстро сориентироваться в разнообразии моделей оригами и усвоить приемы их конструирования.

Дом, книжка, водяная бомбочка, дверь, катамаран, квадратный лист бумаги, блин, треугольник, воздушный змей, рыба, лягушка, квадрат, птица.

\section{4. Условные знаки, принятые в оригами}

Сгиб «долиной»; перегнуть, т.е. наметить складку; повернуть в одной плоскости; сгиб «горой»; складка «молнией»; перевернуть другой стороной; выгнуть наружу; завернуть.

\section{5. Изготовление собственных моделей на онлайн-олимпиаде}


Представление мастер-класс на видеоролике инстаграм, фэйсбук ; выставка работ

\section{ЗАКЛЮЧЕНИЕ:}

Движение «1000 журавликов» возродило интерес к оригами. По всему миру стали издаваться красочные книги, буклеты, журналы посвященные этому искусству. Сейчас центры оригами открыты в 26 государствах планеты.

Япония объявила оригами своим национальным искусством, и каждый уважающий себя японец мастерит фигурки чуть ли не с трех лет. Различные бумажные конструкции: зайчики, веера, фонарики-стали в Японии непременным украшением праздников. В каждом доме обязательно есть шар, сделанный своими руками, «Касудама», - шар, приносящий счастье, как ласково называют его японцы.

Такой шар и многие другие поделки мы делали сами в новом году, и много разных журавлей на региональном фестивале Стерха - кыталык. Условные знаки, принятые в оригами понятны всем и практически не требует дополнительных объяснений. А конструкция настолько проста, что, совершив 2-3 действия, мы получаем готовую игрушку, парусник или загадочную птицу.

Листая схемы за схемой, мы увидели, что складывание игрушек постепенно усложнялась, и, мы испытывали некоторые трудности, но когда несколько раз разбирали и собирали модели, то понимали, что можно логически вычислить последовательность модели, таким образом, мы еще и создавали свои собственные модели.

Фигурку можно раскрасить, нарисовать глазки, ротик, приклеить перья или гребешок. Большое количество разных фигурок позволит нам создать, организовать театр оригами или бумажный зоопарк.

Превращение листа бумаги в игрушку мы принимаем как увлекательную игру, не замечая, что в процессе складывания решаем очень серьезные математические задачи: находим параллели и диагонали, делим целое на части, получаем различные виды треугольников и многогранников, с легкостью ориентируемся на листе бумаги, развиваем моторику пальцев рук, логику, воображение, учимся творить и любить все живое.

\section{Список литературы:}

1. Долженко Г.И. «100 оригами»/художник А.Ю.Долбишева-Ярославль: Академия развития: Академия Холдинг. 2004.-224 с.: ил.-(Умелые руки).

2. Сержантова Т.Б. 365 моделей оригами.-М.: Рольф, Айрис-пресс, 1999.-228 с., с илл.-(Внимание: дети!).

3. Антоева В.Г. Программа по внеурочной деятельности «Оригами. Умелые руки» 2013 г.

\section{Приложения}

1. Презентация

2.Выставка практических работ 
4. Программа вариативной части художественного отделения «Стерх-птица счастья». Автор Антоева В.Г. 2008 г. 